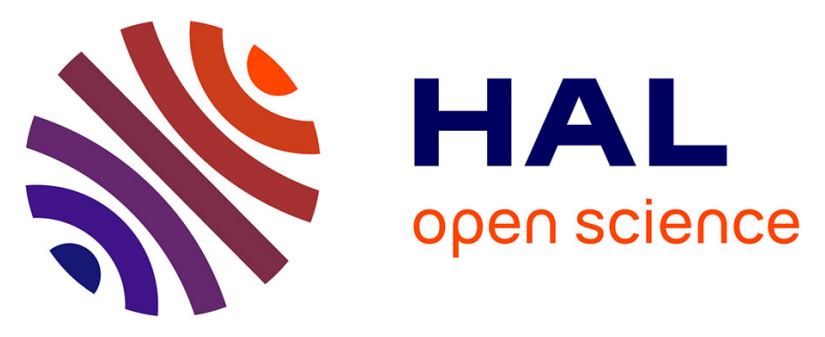

\title{
Involvement of PKA and ERK pathways in ghrelin-induced long-lasting potentiation of excitatory synaptic transmission in the CA1 area of rat hippocampus
}

Mélanie Cavalier, Nadine Crouzin, Azza Ben Sedrine, Marie Celeste de Jesus Ferreira, Janique Guiramand, Catherine Cohen-Solal, Jean-Alain Fehrentz, Jean Martinez, Gérard Barbanel, Michel Vignes

\section{To cite this version:}

Mélanie Cavalier, Nadine Crouzin, Azza Ben Sedrine, Marie Celeste de Jesus Ferreira, Janique Guiramand, et al.. Involvement of PKA and ERK pathways in ghrelin-induced long-lasting potentiation of excitatory synaptic transmission in the CA1 area of rat hippocampus. European Journal of Neuroscience, 2015, 42 (8), 10.1111/ejn.13013 . hal-01218561

\author{
HAL Id: hal-01218561 \\ https://hal.science/hal-01218561
}

Submitted on 17 Jan 2020

HAL is a multi-disciplinary open access archive for the deposit and dissemination of scientific research documents, whether they are published or not. The documents may come from teaching and research institutions in France or abroad, or from public or private research centers.
L'archive ouverte pluridisciplinaire HAL, est destinée au dépôt et à la diffusion de documents scientifiques de niveau recherche, publiés ou non, émanant des établissements d'enseignement et de recherche français ou étrangers, des laboratoires publics ou privés. 
Received Date : 23-Feb-2015

Revised Date : 01-Jul-2015

Accepted Date : 02-Jul-2015

Article type : Research Report

Section Molecular and Synaptic Mechanisms

Involvement of PKA and ERK pathways in ghrelin-induced long-lasting potentiation of excitatory synaptic transmission in the CA1 area of rat hippocampus

Mélanie Cavalier ${ }^{1}$, Nadine Crouzin ${ }^{1}$, Azza Ben Sedrine ${ }^{1}$, Marie Celeste de Jesus Ferreira ${ }^{1}$, Janique Guiramand $^{1}$, Catherine Cohen-Solal ${ }^{1}$, Jean-Alain Fehrentz ${ }^{1}$, Jean Martinez ${ }^{1}$, Gérard Barbanel $^{1}$ and Michel Vignes ${ }^{1} *$

${ }^{1}$ Institut des Biomolécules Max Mousseron, UMR 5247 CNRS-UM1-UM2， 34095 Montpellier Cedex 5, France

*Corresponding author: Dr. Michel Vignes, IBMM, UMR 5247 CNRS-UM1-UM2, Place

E Bataillon, 34095 Montpellier cedex 5, France; Tel: +33 (0)467143699, Fax: +33

(0)467144251, Email: michel.vignes@univ-montp2.fr

Running title: GHS-R1a-induced enduring synaptic potentiation

Keywords:

Hippocampus, plasticity, GHS-R1a, AMPA, NMDA, intracellular calcium

This article has been accepted for publication and undergone full peer review but has not been through the copyediting, typesetting, pagination and proofreading process, which may lead to differences between this version and the Version of Record. Please cite this article as doi: 10.1111/ejn.13013

This article is protected by copyright. All rights reserved. 


\section{ABSTRACT}

Acute effects of ghrelin on excitatory synaptic transmission were evaluated on hippocampal CA1 synapses. Ghrelin triggered an enduring enhancement of synaptic transmission independently of NMDA receptor activation and likely via postsynaptic modifications. This ghrelin-mediated potentiation resulted from the activation of GHS-R1a receptors as it was mimicked by the selective agonist JMV1843 and blocked by the selective antagonist JMV2959. This potentiation also required the activation of PKA and ERK pathways to occur since it was inhibited by KT5720 and U0126, respectively. Moreover it most likely involved $\mathrm{Ca}^{2+}$ influxes as both ghrelin and JMV1843 elicited intracellular $\mathrm{Ca}^{2+}$ increases, which were dependent on the presence of extracellular $\mathrm{Ca}^{2+}$ and mediated by L-type $\mathrm{Ca}^{2+}$ channels opening. In addition, ghrelin potentiated AMPA receptor-mediated $\left[\mathrm{Ca}^{2+}\right] \mathrm{i}$ increases while decreasing NMDA receptor-mediated ones. Thus the potentiation of synaptic transmission by GHS-R1a at hippocampal CA1 excitatory synapses likely results from postsynaptic mechanisms involving PKA and ERK activation, which are producing long-lasting enhancement of AMPA receptor-mediated responses.

\section{INTRODUCTION}

The orexigenic hormone ghrelin, a 28 amino acid octanoylated peptide, was first described as an endogenous peptide predominantly synthetized by the empty stomach, activating hypothalamic neurons responsible for food intake and regulation of energy balance (Andrews, 2011). Beside these well-established functions, several reviews mentioned that ghrelin is also associated with the regulation of several brain activities including reward, drug seeking, ethanol addiction, and memory storage (Dickson et al., 2011; Isokawa, 2012). It thus 
provides an interesting link between the central nervous system and the enteric nervous system, so-called 'the second brain'. Moreover, ghrelin exhibits numerous beneficial actions against neurotoxic challenges such as 1-methyl-4-phenyl-1,2,3,6-tetrahydropyridine exposure (Jiang et al., 2008) or amyloid- $\beta$-1-42 oligomer-induced neurodegeneration (Moon et al., 2011). It also prevents amnesia produced by exposure to the $N$-Methyl-D-Aspartate (NMDA) receptor antagonist dizolcipine (MK801) (Goshadrou et al., 2013).

Ghrelin affects brain activity by binding the growth hormone secretagogue receptor 1a (GHS-R1a), a G protein coupled receptor. GHS-R1a is densely expressed in the hypothalamus, the substantia nigra, the ventral tegmental area (VTA) and throughout the limbic system, including the hippocampus. The activation of GHS-R1a enhances neuronal excitability as demonstrated recently in the substantia nigra pars compacta and CA1 area of the hippocampus (Shi et al., 2013). This increase in excitability could explain the ghrelininduced increases of dopamine in the nucleus accumbens (Jerlhag et al., 2006) and of acetylcholine in the VTA (Jerlhag et al., 2012).

Furthermore, the contribution of constitutively active GHS-R1a receptors to neurophysiological processes is supported by several studies (Pantel et al., 2006; Pazos et al., 2008; Portelli et al., 2012).

GHS-R1a is markedly expressed in the hippocampus (Guan et al., 1997), an essential area for learning and memory. Local infusions of ghrelin induce strong pro-mnesic effects as evidenced by spatial memory tests (Diano et al., 2006; Atcha et al., 2009; Carlini et al., 2010; Chen et al., 2011). Since long-term potentiation (LTP) is considered as the neurophysiological substrate of memory formation in the CA1 area of the hippocampus (Lynch, 2004), positive effects of ghrelin on synaptic transmission, and most particularly on high frequency-induced LTP, are expected. Consistently, enhancements (Diano et al., 2006; Ribeiro et al., 2014), or facilitation (Carlini et al., 2010) of LTP elicited by ghrelin are 
observed, either using acute hippocampal slice preparations or organotypic cultures. In addition, in vivo experiments in the dentate gyrus show that the application of ghrelin could by itself induce a long-lasting increase in excitatory transmission, while having a positive effect only on the maintenance of high frequency-evoked LTP but not on its induction (Chen et al., 2011). These effects of ghrelin likely involve a delayed stimulation of the phosphoinositide-3-kinase (PI3K) and of the extracellular signal-regulated kinases (ERK) pathways (Chen et al., 2011).

Therefore, we have characterized here the effect of the direct stimulation of GHS-R1a on synaptic transmission in the CA1 area of the hippocampus using selective agonists, i.e. octanoylated-ghrelin and a synthetic analog, JMV1843 (Guerlavais et al., 2003), along to the use of a selective antagonist, JMV2959 (Moulin et al., 2007), in order to characterize these responses. Furthermore, as GHS-R1a could raise neuronal excitability by promoting intracellular $\mathrm{Ca}^{2+}\left(\left[\mathrm{Ca}^{2+}\right] \mathrm{i}\right)$ increases via the coupling to $\mathrm{Gq}$ and phospholipase $\mathrm{C}$ (PLC) activation, the effect of GHS-R1a agonists was also evaluated on the $\left[\mathrm{Ca}^{2+}\right] \mathrm{i}$ in cultured hippocampal neurons.

\section{MATERIAL AND METHODS}

Experiments were conducted on acute rat hippocampal slices and cultured rat hippocampal neurons.

\section{Animals}

All experiments were carried out in accordance with the European Community Council Directive of September 22, 2010 (2010/63/UE). This study was approved by the local section of the 'Comité National de Réflexion Ethique sur l'Expérimentation Animale' (C2EA-36). All efforts were made to minimize animal suffering and to reduce the number of rats used. Sprague-Dawley rats were from the Centre d'Elevage Depré (France). 


\section{Materials and drugs}

Culture media (DMEM/Ham F12 with Hepes and 4.5 g/l glucose), Dulbecco's phosphatebuffered saline (Dulbecco's PBS), Versene ${ }^{\mathrm{TM}}$, antibiotics, and fetal calf serum (FCS) were purchased from Invitrogen. Culture dishes were from Nunc.

Ghrelin, D-Amino-phosphonovalerate (AP5) and di-hydroxy-phenyl-glycine (DHPG) were purchased from Abcam Biochemicals. KT-5720, kainate and NMDA were obtained from Sigma and U0126 from Euromedex. KT-5720 and U0126 were used at the efficient concentration recommended by the manufacturer. JMV1843 and JMV2959 were synthesized in the laboratory, and used at efficient doses previously determined (Mousseaux et al., 2006; Moulin et al., 2013).

\section{Hippocampal slice preparation}

Hippocampal slices $(300 \mu \mathrm{m})$ were obtained from male Sprague-Dawley rats. After decapitation, brains were quickly dissected and placed in ice-cold buffer comprising $124 \mathrm{mM}$ $\mathrm{NaCl}, 3.5 \mathrm{mM} \mathrm{KCl}, 25 \mathrm{mM} \mathrm{NaHCO} 3,1.25 \mathrm{mM} \mathrm{NaH} \mathrm{PO}_{4}, 1 \mathrm{mM} \mathrm{CaCl} 2,2 \mathrm{mM} \mathrm{MgSO}$, $10 \mathrm{mM}$ D-glucose, and $10 \mathrm{mM}$ HEPES bubbled with $\mathrm{O}_{2} / \mathrm{CO}_{2}(95 \% / 5 \%)$. Slices were then cut with a Vibratome (VT1000S; Leica, France) and maintained at room temperature for at least $1 \mathrm{~h}$ in the same buffer supplemented with $1 \mathrm{mM} \mathrm{CaCl}_{2}$. This supplemented buffer - also named extracellular medium - was used for further recordings.

\section{Electrophysiological recordings with micro-electrode array (MEA)}

For electrophysiological recordings, slices were transferred to an MEA (MEA60; Multi Channel Systems, Reutlingen, Germany) continually superfused with the above described extracellular medium (flow rate $2 \mathrm{ml} \cdot \mathrm{min}^{-1}$ ) and $\mathrm{kept}$ at $32^{\circ} \mathrm{C}$. Drugs were directly applied in this superfusion. MEA was positioned on the platform of a Leica inverted microscope 
equipped with a CCD camera (CoolSnap, Roper Scientific, France). Images of the hippocampal slice on the MEA were captured in order to accurately map the synaptic signals recorded in the brain slice. MEA comprised 60 extracellular electrodes (Lante et al., 2008): The inter-electrode distance was $200 \mu \mathrm{m}$ and each individual electrode from the array could be used either as a recording or as a stimulatory electrode. A nylon mesh was positioned above the slice to obtain a satisfactory electrical contact between the surface of the slice and the electrode array. Stimulation was achieved with an external stimulator (STG-1004; Multi Channel Systems) by applying biphasic current pulses to one electrode of the array, located in the Schaffer Collateral pathway of the hippocampus. Stimulation intensity (50 to $200 \mu \mathrm{A}$ ) and duration (70 to $200 \mu \mathrm{s})$ were adapted to avoid multiphasic responses due to excessive stimulation (Heuschkel et al., 2002). Field excitatory postsynaptic potentials (fEPSPs) could then be recorded by all the remaining electrodes of the array at the same time. Signals were recorded and analyzed (MC Rack; Multi Channel Systems). Baseline synaptic signals were evoked using $0.066 \mathrm{~Hz}$ frequency stimulation. Slices displaying epileptic-like activity were discarded. Data are presented as means \pm SEM on graphs plotting pooled data. They are expressed as fEPSP amplitudes normalized to their corresponding baseline amplitudes. Each individual (' $n$ ') corresponds to an experiment performed on a slice from an individual animal.

\section{Primary cultures of rat hippocampal neurons}

Primary neuronal cultures were established from 18-day-old embryonic rat hippocampi, as previously described (Blanc et al., 1999; de Jesus Ferreira et al., 2005), with minor modifications. After pre-incubation with Versene ${ }^{\mathrm{TM}}$, hippocampal cells were mechanically dissociated and plated at a density of $2 \times 10^{6}$ cells/dish in 8 -well dishes containing glass coverslips. Culture dishes and coverslips have been previously coated with poly-L-lysine $(15 \mu \mathrm{g} / \mathrm{mL})$ and then with DMEM/HAM F12 containing 10\% FCS. Cells were grown in a 
defined medium containing DMEM/HAM F12, supplemented with $33 \mathrm{mM}$ glucose, $2 \mathrm{mM}$ glutamine, $100 \mathrm{U} / \mathrm{mL}$ penicillin, $100 \mu \mathrm{g} / \mathrm{mL}$ streptomycin, $13 \mathrm{mM}$ sodium bicarbonate, $50 \mu \mathrm{g} / \mathrm{mL}$ transferrin, $0.5 \mu \mathrm{g} / \mathrm{mL}$ insulin, $1 \mathrm{pM} \beta$-estradiol, $3 \mathrm{nM}$ triiodothyronine, $20 \mathrm{nM}$ progesterone, $46 \mathrm{nM}$ sodium selenite, and $100 \mu \mathrm{M}$ putrescine. All experiments were performed on cell cultures grown for at least 7 days in vitro.

\section{Measurements of cytosolic-free $\mathrm{Ca}^{2+}$ concentration}

Intracellular calcium concentration $\left(\left[\mathrm{Ca}^{2+}\right] \mathrm{i}\right)$ was measured with the fluorescent indicator fura-2 (Crouzin et al., 2007). For this purpose, hippocampal cells grown on square $(10 \times 10 \mathrm{~mm})$ glass coverslips were loaded with fura- 2 by a 30 -min incubation at $37{ }^{\circ} \mathrm{C}$ with $5 \mu \mathrm{M}$ fura-2-AM and $0.02 \%$ Pluronic ${ }^{\circledR}$ in the extracellular solution: $124 \mathrm{mM} \mathrm{NaCl}$, $3.5 \mathrm{mM} \mathrm{KCl}, 25 \mathrm{mM} \mathrm{NaHCO} 3,1.25 \mathrm{mM} \mathrm{NaH}_{2} \mathrm{PO}_{4}, 2 \mathrm{mM} \mathrm{CaCl}_{2}, 2 \mathrm{mM} \mathrm{MgSO}, 10 \mathrm{mM}$ D-Glucose and $10 \mathrm{mM}$ HEPES (bubbled with $\mathrm{O}_{2} / \mathrm{CO}_{2}$ : 95/5) pH 7.4. $\left[\mathrm{Ca}^{2+}\right] \mathrm{i}$ was monitored by videomicroscopy. After rinsing, the glass coverslip was transferred to the recording chamber mounted on an inverted microscope (Leica, DMIRB). Fura-2 emission was obtained by exciting alternatively at 340 and $380 \mathrm{~nm}$ with a rotating filter wheel (Sutter Instruments) and by monitoring fluorescent emissions (F340 and F380) at $510 \mathrm{~nm}$. The ratio of emissions at $510 \mathrm{~nm}(\mathrm{~F} 340 / \mathrm{F} 380)$ was recorded every 2 s. Fluorescent signals were collected with a CCD camera (Hamamatsu), digitized, and analyzed with image analysis software (Acquacosmos, Hamamatsu). Throughout recordings, coverslips were continually superfused with the extracellular solution thermostated at $37^{\circ} \mathrm{C}$. Some experiments were performed while omitting $\mathrm{Ca}^{2+}$ in the extracellular medium (' $\mathrm{Ca}^{2+}$-free' medium). Drug application was performed with a gravity-fed system. The ' $n$ ' values represent the entire population of cells recorded in at least 3 independent cultures. On the graphs, data are presented as 
averages \pm S.E.M. of fura2 fluorescence ratios obtained in individual cells. Ratios have been normalized to their respective baseline value measured prior to any treatment.

\section{Statistics}

All statistical analyses were performed using SigmaStat software (SigmaPlot 12.0, Systat Software, San Jose, CA) and the level of significance was settled at $P<0.05$. Data are presented as means \pm SEM.

One-way analyses of variance followed by Bonferroni method for multiple comparisons were used to test the significance of the level of synaptic potentiation elicited by ghrelin or JMV1843. Two-way analyses of variance followed by Holm-Sidak method for multiple comparisons were used to test the significance of the effect of various drugs on these responses.

For the analyses of calcium transients, areas above peaks in each individual cell were estimated using SigmaPlot software. Values were then compared using either one-way ANOVA on repeated measures for dose-response experiments, or using $t$-test for comparing two experimental conditions. Finally, the statistical significance of the difference between $\left[\mathrm{Ca}^{2+}\right] \mathrm{i}$ rises elicited by glutamatergic agonists in control and treated cells was evaluated by performing a two-way ANOVA on repeated measured followed by Holm-Sidak method for multiple comparisons.

\section{RESULTS}

The application of ghrelin (concentration range: $1-100 \mathrm{nM}$ for $20 \mathrm{~min} ; n=9$ each) elicited an enduring potentiation of the excitatory transmission between Schaffer collaterals and CA1 neurons, which was maintained at least 50 min following ghrelin washout (Figure 1A). The effect of ghrelin was concentration-dependent $\left(F_{2,6866}=441, P<0.001\right)$. It was significantly 
enhanced $(P<0.0001)$ as ghrelin concentration increased from $1 \mathrm{nM}$ to $10 \mathrm{nM}$ in the superfusion medium, but was not significantly different $(P=0.99)$ when using a further 10-fold higher concentration (Figure 1A). For subsequent experiments, ghrelin was applied at a concentration of $10 \mathrm{nM}$. Under these conditions, $50 \mathrm{~min}$ after ghrelin washout, the fEPSP mean amplitude reached $158 \pm 4 \%$ of control amplitude. The paired-pulse facilitation ratios, obtained by applying two pulses separated by $50 \mathrm{~ms}$ interval, were $1.22 \pm 0.05(n=5)$ prior to ghrelin $(10 \mathrm{nM})$ application and $1.21 \pm 0.04(n=5)$ once a stable potentiation had taken place (Figure 1B). These values were not significantly different $(P=0.29)$, suggesting that the ghrelin-induced synaptic potentiation most likely occurred via postsynaptic mechanisms.

Then we verified that the ghrelin-induced potentiation occurred via the activation of GHSR1a. For this, the effect of JMV2959, a selective GHS-R1a antagonist, was tested at a concentration which blocked the biological responses elicited by $10 \mathrm{nM}$ ghrelin (Moulin et al., 2013). In the presence of JMV2959 (100 nM), the effect of ghrelin (10 nM) was completely blocked $\left(F_{1,4372}=1219, P<0.001\right.$ when comparing ghrelin responses either in the absence or the presence of JMV2959; Figure 2A). It is noticeable that JMV2959 had no per se effect on synaptic transmission. Moreover the selective GHS-R1a agonist, JMV1843 $(100 \mathrm{nM})$, also triggered a robust and long-lasting enhancement of synaptic transmission $(n=$ 9, $P<0.001$ as compared to basal transmission) (Figure 2B). At the concentration tested, JMV 1843 is known to produce maximal effect on GHS-R1a (Mousseaux et al., 2006).

Fifty min after JMV1843 washout, the fEPSP mean amplitude reached $148 \pm 10 \%$ of control amplitude $(P<0.002$, as compared to basal). The JMV1843-induced synaptic potentiation was also blocked by JMV2959 (both drugs at $100 \mathrm{nM}, n=5$; data not shown).

Next, the dependence on NMDA receptor activation of ghrelin-induced potentiation of fEPSP was tested. To this aim, AP5 $(25 \mu \mathrm{M} ; n=9)$, a selective NMDA receptor antagonist, was applied prior to ghrelin. Under these conditions, the potentiating action of ghrelin was 
significantly enhanced $\left(F_{1,4985}=751, P<0.001\right.$, as compared to the effect of ghrelin in the absence of AP5) and fEPSP mean amplitude reached $240 \pm 40 \%$ of control amplitude 50 min after ghrelin wash-out $(P=0.029$ as compared to basal; Figure 3). Similar data were obtained when GHS-R1a were activated by JMV1843 (not shown).

The recruitment of intracellular pathways to mediate long-lasting synaptic changes was then further evaluated. In this line, we previously demonstrated that the stimulation of the cAMP/PKA pathway was central to synaptic potentiation and did not require NMDA receptor activation (Lante et al., 2006). The application of the selective PKA inhibitor, KT5720 $(250 \mathrm{nM})$, efficiently fully prevented the ghrelin-mediated synaptic potentiation $\left(F_{1,3965}=\right.$ 953, $P<0.001$, when comparing the effects of ghrelin either in the absence or the presence of KT5720; Figure 4A). In the presence of KT5720, ghrelin did not elicit any significant modification of synaptic transmission ( $P=0.085$, as compared to basal transmission). We then verified whether the MAP-kinase pathway, activated after PKA stimulation, could also be involved in ghrelin effect on synaptic transmission. For this, the ERK kinase inhibitor U0126 $(10 \mu \mathrm{M})$ was tested. This inhibitor also significantly prevented the ghrelin-elicited synaptic potentiation $\left(F_{1,4849}=1082, P<0.001\right.$, when comparing the effects of ghrelin in the absence or the presence of U0126; Figure 4B). Taken together, these data indicate that ghrelin-induced synaptic potentiation results from the activation of GHS-R1a followed by the stimulation of both cAMP/PKA and MAP-kinase pathways.

GHS-R1a may couple the phospholipase C (PLC) pathway thus triggering intracellular $\mathrm{Ca}^{2+}$ mobilization after IP3 production (Mousseaux et al., 2006; Shi et al., 2013). We have thus evaluated the impact of ghrelin and JMV1843 on $\left[\mathrm{Ca}^{2+}\right] \mathrm{i}$ in cultured hippocampal neurons. Both ghrelin (Figure 5A) and JMV1843 (Figure 5B) elicited concentrationdependent increases in $\left[\mathrm{Ca}^{2+}\right] \mathrm{i}(P=0.002$ and $P<0.001$, respectively). Ghrelin significant effects were detected from a $1 \mathrm{nM}$ concentration $(P=0.008$, as compared to basal $)$ and 
reached maximal amplitude at $100 \mathrm{nM}$. In order to test whether ghrelin- and JMV1843mediated increases in $\left[\mathrm{Ca}^{2+}\right]$ i effectively resulted from the mobilization of $\left[\mathrm{Ca}^{2+}\right]$ i from IP3sensitive internal stores, experiments were carried out in $\mathrm{Ca}^{2+}$-free extracellular medium. Under these conditions, ghrelin induced changes in $\left[\mathrm{Ca}^{2+}\right] \mathrm{i}$ were strongly reduced $(P$ $=0.0039$ and $P=0.002$ for the comparison of the effect of ghrelin $10 \mathrm{nM}$ and $100 \mathrm{nM}$, respectively, in the presence of the absence of extracellular calcium; Figure 5C). Moreover, JMV1843 $(100 \mathrm{nM})$ was unable to induce any significant $\left[\mathrm{Ca}^{2+}\right] \mathrm{i}$ response $(P=0.44$ versus basal, $P=0.007$, as compared to the effect of JMV1843, in the presence of extracellular calcium; Figure 5D). By contrast, under the same experimental conditions, the metabotropic glutamate $1 / 5$ receptor agonist DHPG still triggered robust $\left[\mathrm{Ca}^{2+}\right]$ i transients $(P<0.001$, as compared to basal; Figures 5C and 5D). GHS-R1a activation thus mainly produced intracellular $\mathrm{Ca}^{2+}$ increase in hippocampal neurons by promoting $\mathrm{Ca}^{2+}$ influx from the extracellular medium. In our hands, L-type VGCC largely mediates the $\mathrm{Ca}^{2+}$ influxes observed after depolarization in hippocampal cultures (Pringos et al., 2012). Thus, verapamil, a L-type VGCC blocker was tested. In the presence of verapamil $(50 \mu \mathrm{M})$, the ghrelininduced $\left[\mathrm{Ca}^{2+}\right] \mathrm{i}$ increase was almost fully inhibited $(P<0.001$, as compared to the effect of ghrelin, in the absence of verapamil; Figure $5 \mathrm{E}$ ), although a residual $\mathrm{K}^{+}$-mediated $\left[\mathrm{Ca}^{2+}\right]$ i rise could still be evidenced $\left(P<0.001\right.$, as compared to the effect of $\mathrm{K}^{+}$in the absence of verapamil; Figure 5F).

As we found that GHS-R1a stimulation produced a strong potentiation of the glutamatergic AMPA receptor-mediated synaptic transmission in hippocampal slices likely via postsynaptic mechanisms, we next evaluated whether GHS-R1a could directly modulate the activity of ionotropic glutamate receptors, i.e. AMPA/KA and NMDA receptors. In order to test this hypothesis, cells were pre-incubated for 30 min with $100 \mathrm{nM} \mathrm{JMV} 1843$ before the application of either kainate $(20 \mu \mathrm{M})$ or NMDA $(10 \mu \mathrm{M})$. Both ionotropic glutamate receptor 
agonists induced a sustained increase in $\left[\mathrm{Ca}^{2+}\right] \mathrm{i}(P<0.001$, as compared to basal). Pretreatment with JMV1843 significantly enhanced kainate-mediated $\left[\mathrm{Ca}^{2+}\right] \mathrm{i}$ changes $\left(F_{1,10448}=21, P<0.001 ;\right.$ Figure $\left.6 \mathrm{~A}\right)$. Holm-Sidak post-hoc analysis indicated a significant difference $(P<0.0005)$ for data points obtained between time 2 and 3 min. Conversely, a similar pretreatment significantly decreased NMDA-elicited $\left[\mathrm{Ca}^{2+}\right] \mathrm{i}$ rises $\left(F_{1,11248}=134, P<\right.$ 0.001; Figure 6B), with a significant effect $(P<0.0005)$ for data points obtained between time 2 and 4 min.. This confirmed that ghrelin could modulate synaptic transmission by potentiating AMPA/KA receptor-associated physiological responses independently of NMDA receptor activation.

\section{DISCUSSION}

Recent studies showed that the orexigenic peptide ghrelin induced a strong modulation of hippocampal function which may be involved in the positive effect on cognition and learning mediated by hunger (Carlini et al., 2002; Diano et al., 2006; Olszewski et al., 2008; Andrews, 2011; Davis et al., 2011). However, the mechanisms involved in this potentiation are not completely deciphered as ghrelin may activate a plethora of molecular mechanisms. Here, we show on rat hippocampal slices that ghrelin potently enhances synaptic transmission by activating PKA and ERK pathways. This effect of ghrelin results from the activation of GHSR1a, as evidenced with selective ligands, i.e. the agonist JMV1843 and the antagonist JMV2959.

Ghrelin signaling in the hippocampus is often related to the induction of PKA pathway. Indeed, activation of PKA signaling occurred in organotypic hippocampal slices incubated with relatively higher concentrations of ghrelin (from $50 \mathrm{nM}$ to $1 \mu \mathrm{M}$ ), as compared to those used herewith. This activation resulted in the phosphorylation of CREB, and in fine, in the 
phosphorylation of the GluN1 subunit of the NMDA receptor (Cuellar \& Isokawa, 2011). As far as long-term mechanisms of potentiation are concerned, we find here that the stimulation of both PKA and ERK pathways are critical steps in the ghrelin-induced long-lasting synaptic enhancement in the CA1 area of the hippocampus. It is known for long that PKA activation is crucial to trigger consolidated synaptic plasticity produced either electrically or chemically (Kandel, 2001). ERK phosphorylation downstream PKA activation is also required for the consolidation of synaptic plasticity in many experimental models as previously reported (Kanterewicz et al., 2000; Lynch, 2004; Sweatt, 2004). It is noticeable that activation of PI3Kinase-Akt signaling in the dentate gyrus may also stand for the occurrence of ghrelinevoked hippocampal synaptic plasticity (Chen et al., 2011), and also most likely for the enhancement of food-intake induced by intra-hippocampal infusion of ghrelin (Kanoski et al., 2013). Thus our data further add to the complexity on the intracellular pathways activated by ghrelin in central neurons.

Contrasting results regarding the involvement of NMDA receptor activation in ghrelinmediated effects have been reported so far. In organotypic culture of hippocampal slices, NMDA receptor blockade actually inhibited the ghrelin-induced CREB activation (Cuellar \& Isokawa, 2011), as well as AMPA receptor insertion (Ribeiro et al., 2014), suggesting that ghrelin could induce the potentiation of excitatory synaptic transmission via an enhancement of NMDA receptor activity. By contrast, in vivo, the ghrelin-mediated enhancement of excitatory synaptic transmission in the dentate gyrus was insensitive to NMDA receptor blockade (Chen et al., 2011). Using both acute hippocampal slice preparations and primary neuronal cultures, our data show an interaction between ghrelin-induced potentiation of excitatory synaptic transmission and NMDA receptor activation. Indeed, we firstly observed that NMDA receptor blockade enhanced the ghrelin-mediated synaptic potentiation in slices, 
and secondly that ghrelin decreased the NMDA receptor-associated $\mathrm{Ca}^{2+}$ influx in primary hippocampal neuron cultures.

The discrepancies in NMDA receptor dependency could be related to the experimental models used and/or to the metabolic environment of the neurons encountered in these preparations (Yang et al., 2011; Haam et al., 2014). Indeed, the effect of ghrelin on synaptic transmission in the hypothalamus is linked to the activity of the AMP activated kinase, a sensor for cellular metabolic status. Similarly, as reported in NPY-positive hypothalamic neurons, ghrelin-induced $\left[\mathrm{Ca}^{2+}\right] \mathrm{i}$ changes require AMP activated kinase activity (Kohno et al., 2008).

On the other hand, we found that GHS-R1a activation reinforced AMPA receptormediated responses in hippocampal neurons and that the paired-pulse facilitation ratio was unchanged after ghrelin treatment, consistent with the prominent recruitment of postsynaptic mechanisms for obtaining the enduring potentiation of synaptic transmission (Ribeiro et al., 2014). Our data therefore support the possibility that ghrelin-induced potentiation relies upon an enhancement of AMPA receptor-mediated synaptic transmission by promoting the postsynaptic insertion of AMPA receptors.

In the CA1 area of acute hippocampal slices, the ghrelin-induced long-lasting enhancement of synaptic transmission that we observe here is reminiscent of forms of longterm potentiation independent of NMDA receptors and dependent on PKA activation, which have been identified in CA3 (Weisskopf et al., 1994) but also in CA1 (Lante et al., 2006; Lante et al., 2008) areas of the hippocampus, as well as in amygdala (Huang \& Kandel, 2007).

The ghrelin-induced activation of PKA may initially result from an increase in $\left[\mathrm{Ca}^{2+}\right] \mathrm{i}$ and subsequent stimulation of $\mathrm{Ca}^{2+}$-dependent adenylyl cyclases (Chetkovich et al., 1991) to produce cAMP. Indeed, GHS-R1a may couple Gq (Mousseaux et al., 2006; Lau et al., 2009; 
Sun et al., 2010) and subsequently activate PLC and mobilize $\mathrm{Ca}^{2+}$ from inositol-1,4,5trisphosphate $\left(\mathrm{IP}_{3}\right)$-sensitive stores (Camina et al., 2003; Falls et al., 2006). We verified that ghrelin and JMV1843 actually triggered increases in $\left[\mathrm{Ca}^{2+}\right] \mathrm{i}$ in hippocampal neurons. More precisely, we found here that $\left[\mathrm{Ca}^{2+}\right] \mathrm{i}$ changes elicited by GHS-R1a activation mainly resulted from influxes, as no $\left[\mathrm{Ca}^{2+}\right] \mathrm{i}$ changes could be observed in the absence of extracellular calcium. Moreover, we observe here that ghrelin-induced $\left[\mathrm{Ca}^{2+}\right] \mathrm{i}$ rises almost exclusively depend on L-type $\mathrm{Ca}^{2+}$ channels opening as evidenced by the strong inhibitory action of verapamil, a L-type $\mathrm{Ca}^{2+}$ channel blocker. Interestingly, the requirement of extracellular $\mathrm{Ca}^{2+}$ for ghrelin to elicit $\left[\mathrm{Ca}^{2+}\right] \mathrm{i}$ increases and to produce its neurophysiological effects has also been evidenced in neuronal populations involved in food intake and neuroendocrine regulations. For instance, ghrelin induces $\left[\mathrm{Ca}^{2+}\right] \mathrm{i}$ increases dependent on both extracellular $\mathrm{Ca}^{2+}$ and PKA activation in Neuropeptide Y containing neurons of the arcuate nucleus of the hypothalamus (Kohno et al., 2008). Similarly, ghrelin triggers $\left[\mathrm{Ca}^{2+}\right] \mathrm{i}$ rises and growth hormone release in an extracellular $\mathrm{Ca}^{2+}$ dependent manner in goldfish pituitary cells (Grey \& Chang, 2009). Thus, in these neuronal populations, ghrelin-associated signaling seems to mainly involve $\mathrm{Ca}^{2+}$ influxes through voltage-gated channels, rather than $\mathrm{Ca}^{2+}$ mobilization from internal stores. This is further supported by the fact that, in these experimental models, ghrelin-mediated $\left[\mathrm{Ca}^{2+}\right] \mathrm{i}$ rises are sensitive to N-type (Kohno et al., 2008) or L-type (Grey \& Chang, 2009) $\mathrm{Ca}^{2+}$ channel blockade, respectively. Moreover, $\mathrm{Ca}^{2+}$ channel opening is required for observing excitatory effects of ghrelin on hypothalamic GHRH neurons (Osterstock et al., 2010). By contrast, blocking IP3 receptors with xestospongin-C does not seem to alter ghrelin-mediated CREB activation in CA1 hippocampal neurons (Cuellar \& Isokawa, 2011).

The intracellular $\mathrm{Ca}^{2+}$ changes elicited by ghrelin could thus result from the activation of voltage-gated $\mathrm{Ca}^{2+}$ channels subsequent to membrane depolarization. In this line, rapid 
depolarizing responses to ghrelin have been observed in various neuronal subtypes, including substantia nigra, dorsal root ganglion and CA1 hippocampal (Shi et al., 2013), as well as cerebellar (Sun et al., 2014) neurons. Ghrelin enhances spike frequency likely by inhibiting voltage-gated $\mathrm{K}^{+}$channels, as recently described in CA1 hippocampal neurons (Shi et al., 2013). Therefore, long-lasting potentiation of excitatory synaptic transmission may be initiated by the depolarizing action of ghrelin, which leads to the activation of intracellular pathways resulting in the onset of consolidated enhancements of excitatory transmission.

\section{LEGENDS FOR THE FIGURES}

Figure 1: Action of ghrelin on CA1 synaptic transmission. (A) Long-lasting enhancement of excitatory synaptic transmission by ghrelin applied at 1,10 or $100 \mathrm{nM}$ for $20 \min (n=9$ each). Field EPSP were evoked in the CA1 area by stimulating the Schaffer collateral pathway and recorded with MEA. Graphs are illustrated by representative traces extracted before and after the application of ghrelin as indicated by numbers. (B) Paired-pulse facilitation ratio before and after the infusion of $100 \mathrm{nM}$ ghrelin. Two pulses of stimulation were applied with $50 \mathrm{~ms}$ interval duration. Paired-pulse facilitation ratio was calculated by dividing the amplitude of the second fEPSP by the amplitude of the first one. On the graph, data are averages of paired-pulse ratios $( \pm$ SEM) calculated from 5 independent experiments. Representative traces before and after the application of ghrelin are shown in the upper panel.

Figure 2: Pharmacological characterization of the ghrelin action on excitatory transmission in the CA1 hippocampal area. (A) Effect of the specific GHS-R1a antagonist, JMV2959, on ghrelin-induced synaptic potentiation. JMV2959 (100 nM) was applied 10 min prior to ghrelin (10 $\mathrm{nM}$ for $20 \mathrm{~min})$ and then maintained throughout the fEPSP recording $(n=7)$

Graphs are illustrated by representative traces extracted before and after the application of 
ghrelin, as indicated by numbers. In the presence of JMV2959, ghrelin did not elicit any significant modification of synaptic transmission $(P=0.34$, as compared to basal transmission). (B). Effect of the specific GHS-R1a agonist, JMV1843 (100 nM) on excitatory synaptic transmission $(n=9)$. Graphs are illustrated by representative traces extracted before and after the application of JMV1843 as indicated by numbers.

Figure 3: Effect of ghrelin on synaptic transmission under NMDA receptor blockade. The specific NMDA receptor antagonist, AP5 $(25 \mu \mathrm{M})$, was applied 10 min prior to ghrelin (10 $\mathrm{nM}$ for $20 \mathrm{~min})$ and then maintained throughout the fEPSP recording $(n=9)$. Graphs are illustrated by representative traces extracted before and after the application of ghrelin, as indicated by numbers.

Figure 4: Intracellular pathways involved in the ghrelin-mediated enduring synaptic potentiation. (A) Effect of PKA blockade with KT5720 (250 nM, $n=7)$. (B) Effect of the MEK inhibitor U0126 (10 $\mu \mathrm{M}, n=7)$. Blockers were applied 10 min prior to ghrelin $(10 \mathrm{nM}$ for $20 \mathrm{~min}$ ), and then maintained throughout the fEPSP recording. Per se, neither KT5720 nor U0126 had any effect on basal synaptic transmission.

Figure 5: Intracellular $\left[\mathrm{Ca}^{2+}\right]$ i changes induced by either ghrelin or JMV1843 in cultured hippocampal neurons. (A, B) Concentration-dependent effects of ghrelin ( $n=187$ cells) (A) and JMV1843 $\left(n=207\right.$ cells) (B) on $\left[\mathrm{Ca}^{2+}\right] \mathrm{i}$ in the presence of $\mathrm{Ca}^{2+}$ in extracellular medium. (C, D) Effects of ghrelin (10 or $100 \mathrm{nM} ; n=338$ cells) and JMV1843 (300 nM; $n=258$ cells) on $\left[\mathrm{Ca}^{2+}\right] \mathrm{i}$ in the absence of $\mathrm{Ca}^{2+}$ in extracellular medium. Under these experimental conditions, DHPG $(10 \mu \mathrm{M})$ application was performed as a positive control for intracellular $\mathrm{Ca}^{2+}$ mobilization. (E, F) Effect of L-type VGCC blocker verapamil (50 $\left.\mu \mathrm{M}\right)$ on ghrelin- 
mediated $\left[\mathrm{Ca}^{2+}\right]$ i rise. Control experiment (E) was performed by applying ghrelin $(100 \mathrm{nM})$ and then $\mathrm{K}^{+}(30 \mathrm{mM})(n=120$ cells $)$. Verapamil $(\mathrm{F})$ was applied 2 min prior to ghrelin and $\mathrm{K}^{+}(n=95$ cells $)$. Data presented in $\mathrm{E}$ and $\mathrm{F}$ was obtained from cells grown on different coverslips. Each drug was applied for 1 min at the indicated concentrations.

Figure 6: Modulation of AMPA and NMDA receptor-mediated $\left[\mathrm{Ca}^{2+}\right]$ i rises by JMV1843. $\left[\mathrm{Ca}^{2+}\right] \mathrm{i}$ changes mediated by either $20 \mu \mathrm{M}$ kainate (A) or $10 \mu \mathrm{M}$ NMDA (B) were measured in neurons pretreated (filled circles) or not (open circles) with the specific GHS-R1a agonist, JMV1843 (100 nM for $30 \mathrm{~min}$ ). Glutamate receptor agonists were applied for $1 \mathrm{~min}$. On the graphs, data obtained from pretreated cells have been superimposed with those obtained from their corresponding control cells without pretreatment. In (A) data are averages of ratios from 257 and 101 cells for control and pretreated cultures, respectively. In (B) data are averages of ratios from 241 and 209 cells for control and pretreated cultures, respectively. Data have been normalized against the fura 2 ratio measured in control cells prior to any treatment. * indicates $P<0.001$ and $* *$ indicates $P<0.0005$ when comparing data from control $v s$ pretreated cells.

Acknowledgements:

This work was supported by grants from CNRS and the French Ministry for Higher Education and Scientific Research. The authors have no conflict of interest of any kind to declare. 


\section{References}

Andrews, Z.B. (2011) Central mechanisms involved in the orexigenic actions of ghrelin. Peptides, 32, 2248-2255.

Atcha, Z., Chen, W.S., Ong, A.B., Wong, F.K., Neo, A., Browne, E.R., Witherington, J. \& Pemberton, D.J. (2009) Cognitive enhancing effects of ghrelin receptor agonists. Psychopharmacology (Berl), 206, 415-427.

Blanc, E.M., Jallageas, M., Recasens, M. \& Guiramand, J. (1999) Potentiation of glutamatergic agonist-induced inositol phosphate formation by basic fibroblast growth factor is related to developmental features in hippocampal cultures: neuronal survival and glial cell proliferation. Eur J Neurosci, 11, 3377-3386.

Camina, J.P., Carreira, M.C., Micic, D., Pombo, M., Kelestimur, F., Dieguez, C. \& Casanueva, F.F. (2003) Regulation of ghrelin secretion and action. Endocrine, 22, 5-12.

Carlini, V.P., Monzon, M.E., Varas, M.M., Cragnolini, A.B., Schioth, H.B., Scimonelli, T.N. \& de Barioglio, S.R. (2002) Ghrelin increases anxiety-like behavior and memory retention in rats. Biochem Biophys Res Commun, 299, 739-743.

Carlini, V.P., Perez, M.F., Salde, E., Schioth, H.B., Ramirez, O.A. \& de Barioglio, S.R. (2010) Ghrelin induced memory facilitation implicates nitric oxide synthase activation and decrease in the threshold to promote LTP in hippocampal dentate gyrus. Physiol Behav, 101, 117-123.

Chen, L., Xing, T., Wang, M., Miao, Y., Tang, M., Chen, J., Li, G. \& Ruan, D.Y. (2011) Local infusion of ghrelin enhanced hippocampal synaptic plasticity and spatial memory through activation of phosphoinositide 3-kinase in the dentate gyrus of adult rats. Eur J Neurosci, 33, 266-275.

Chetkovich, D.M., Gray, R., Johnston, D. \& Sweatt, J.D. (1991) N-methyl-D-aspartate receptor activation increases cAMP levels and voltage-gated $\mathrm{Ca} 2+$ channel activity in area CA1 of hippocampus. Proc Natl Acad Sci U S A, 88, 64676471.

Crouzin, N., Ferreira, M.C.D.J., Cohen-Solal, C., Aimar, R.F., Vignes, M. \& Guiramand, J. (2007) alpha-Tocopherol-mediated long-lasting protection against oxidative damage involves an attenuation of calcium entry through TRP-like channels in cultured hippocampal neurons. Free Radic Biol Med, 42, 1326-1337.

Cuellar, J.N. \& Isokawa, M. (2011) Ghrelin-induced activation of cAMP signal transduction and its negative regulation by endocannabinoids in the hippocampus. Neuropharmacology, 60, 842-851. 
Davis, J.F., Choi, D.L., Clegg, D.J. \& Benoit, S.C. (2011) Signaling through the ghrelin receptor modulates hippocampal function and meal anticipation in mice. Physiol Behav, 103, 39-43.

de Jesus Ferreira, M.C., Crouzin, N., Barbanel, G., Cohen-Solal, C., Recasens, M., Vignes, M. \& Guiramand, J. (2005) A transient treatment of hippocampal neurons with alpha-tocopherol induces a long-lasting protection against oxidative damage via a genomic action. Free Radic Biol Med, 39, 1009-1020.

Diano, S., Farr, S.A., Benoit, S.C., McNay, E.C., da Silva, I., Horvath, B., Gaskin, F.S., Nonaka, N., Jaeger, L.B., Banks, W.A., Morley, J.E., Pinto, S., Sherwin, R.S., Xu, L., Yamada, K.A., Sleeman, M.W., Tschop, M.H. \& Horvath, T.L. (2006) Ghrelin controls hippocampal spine synapse density and memory performance. Nat Neurosci, 9, 381-388.

Dickson, S.L., Egecioglu, E., Landgren, S., Skibicka, K.P., Engel, J.A. \& Jerlhag, E. (2011) The role of the central ghrelin system in reward from food and chemical drugs. Mol Cell Endocrinol, 340, 80-87.

Falls, H.D., Dayton, B.D., Fry, D.G., Ogiela, C.A., Schaefer, V.G., Brodjian, S., Reilly, R.M., Collins, C.A. \& Kaszubska, W. (2006) Characterization of ghrelin receptor activity in a rat pituitary cell line RC-4B/C. J Mol Endocrinol, 37, 5162.

Goshadrou, F., Kermani, M., Ronaghi, A. \& Sajjadi, S. (2013) The effect of ghrelin on MK801 induced memory impairment in rats. Peptides, 44, 60-65.

Grey, C.L. \& Chang, J.P. (2009) Ghrelin-induced growth hormone release from goldfish pituitary cells involves voltage-sensitive calcium channels. Gen Comp Endocrinol, 160, 148-157.

Guan, X.M., Yu, H., Palyha, O.C., McKee, K.K., Feighner, S.D., Sirinathsinghji, D.J., Smith, R.G., Van der Ploeg, L.H. \& Howard, A.D. (1997) Distribution of mRNA encoding the growth hormone secretagogue receptor in brain and peripheral tissues. Brain Res Mol Brain Res, 48, 23-29.

Guerlavais, V., Boeglin, D., Mousseaux, D., Oiry, C., Heitz, A., Deghenghi, R., Locatelli, V., Torsello, A., Ghe, C., Catapano, F., Muccioli, G., Galleyrand, J.C., Fehrentz, J.A. \& Martinez, J. (2003) New active series of growth hormone secretagogues. J Med Chem, 46, 1191-1203.

Haam, J., Halmos, K.C., Di, S. \& Tasker, J.G. (2014) Nutritional state-dependent ghrelin activation of vasopressin neurons via retrograde trans-neuronal-glial stimulation of excitatory GABA circuits. J Neurosci, 34, 6201-6213.

Heuschkel, M.O., Fejtl, M., Raggenbass, M., Bertrand, D. \& Renaud, P. (2002) A threedimensional multi-electrode array for multi-site stimulation and recording in acute brain slices. J Neurosci Methods, 114, 135-148. 
Huang, Y.Y. \& Kandel, E.R. (2007) Low-frequency stimulation induces a pathway-specific late phase of LTP in the amygdala that is mediated by PKA and dependent on protein synthesis. Learn Mem, 14, 497-503.

Isokawa, M. (2012) Cellular signal mechanisms of reward-related plasticity in the hippocampus. Neural Plast, 2012, 945373.

Jerlhag, E., Egecioglu, E., Dickson, S.L., Andersson, M., Svensson, L. \& Engel, J.A. (2006) Ghrelin stimulates locomotor activity and accumbal dopamine-overflow via central cholinergic systems in mice: implications for its involvement in brain reward. Addict Biol, 11, 45-54.

Jerlhag, E., Janson, A.C., Waters, S. \& Engel, J.A. (2012) Concomitant release of ventral tegmental acetylcholine and accumbal dopamine by ghrelin in rats. PLoS One, 7, e49557.

Jiang, H., Li, L.J., Wang, J. \& Xie, J.X. (2008) Ghrelin antagonizes MPTP-induced neurotoxicity to the dopaminergic neurons in mouse substantia nigra. Exp Neurol, 212, 532-537.

Kandel, E.R. (2001) The molecular biology of memory storage: a dialogue between genes and synapses. Science, 294, 1030-1038.

Kanoski, S.E., Fortin, S.M., Ricks, K.M. \& Grill, H.J. (2013) Ghrelin signaling in the ventral hippocampus stimulates learned and motivational aspects of feeding via PI3KAkt signaling. Biol Psychiatry, 73, 915-923.

Kanterewicz, B.I., Urban, N.N., McMahon, D.B., Norman, E.D., Giffen, L.J., Favata, M.F., Scherle, P.A., Trzskos, J.M., Barrionuevo, G. \& Klann, E. (2000) The extracellular signal-regulated kinase cascade is required for NMDA receptorindependent LTP in area CA1 but not area CA3 of the hippocampus. $J$ Neurosci, 20, 3057-3066.

Kohno, D., Sone, H., Minokoshi, Y. \& Yada, T. (2008) Ghrelin raises [Ca2+]i via AMPK in hypothalamic arcuate nucleus NPY neurons. Biochem Biophys Res Commun, 366, 388-392.

Lante, F., Cavalier, M., Cohen-Solal, C., Guiramand, J. \& Vignes, M. (2006) Developmental switch from LTD to LTP in low frequency-induced plasticity. Hippocampus, 16, 981-989.

Lante, F., Crouzin, N. \& Vignes, M. (2008) Unveiling novel forms of hippocampal synaptic plasticity with microelectrode arrays. J Integr Neurosci, 7, 249-270.

Lau, P.N., Chow, K.B., Chan, C.B., Cheng, C.H. \& Wise, H. (2009) The constitutive activity of the ghrelin receptor attenuates apoptosis via a protein kinase C-dependent pathway. Mol Cell Endocrinol, 299, 232-239.

Lynch, M.A. (2004) Long-term potentiation and memory. Physiol Rev, 84, 87-136. 
Moon, M., Choi, J.G., Nam, D.W., Hong, H.S., Choi, Y.J., Oh, M.S. \& Mook-Jung, I. (2011) Ghrelin ameliorates cognitive dysfunction and neurodegeneration in intrahippocampal amyloid-beta1-42 oligomer-injected mice. J Alzheimers Dis, 23, 147-159.

Moulin, A., Brunel, L., Boeglin, D., Demange, L., Ryan, J., M'Kadmi, C., Denoyelle, S., Martinez, J. \& Fehrentz, J.A. (2013) The 1,2,4-triazole as a scaffold for the design of ghrelin receptor ligands: development of JMV 2959, a potent antagonist. Amino Acids, 44, 301-314.

Moulin, A., Demange, L., Berge, G., Gagne, D., Ryan, J., Mousseaux, D., Heitz, A., Perrissoud, D., Locatelli, V., Torsello, A., Galleyrand, J.C., Fehrentz, J.A. \& Martinez, J. (2007) Toward potent ghrelin receptor ligands based on trisubstituted 1,2,4-triazole structure. 2. Synthesis and pharmacological in vitro and in vivo evaluations. $J$ Med Chem, 50, 5790-5806.

Mousseaux, D., Le Gallic, L., Ryan, J., Oiry, C., Gagne, D., Fehrentz, J.A., Galleyrand, J.C. \& Martinez, J. (2006) Regulation of ERK1/2 activity by ghrelin-activated growth hormone secretagogue receptor $1 \mathrm{~A}$ involves a PLC/PKCvarepsilon pathway. Br J Pharmacol, 148, 350-365.

Olszewski, P.K., Schioth, H.B. \& Levine, A.S. (2008) Ghrelin in the CNS: from hunger to a rewarding and memorable meal? Brain Res Rev, 58, 160-170.

Osterstock, G., Escobar, P., Mitutsova, V., Gouty-Colomer, L.A., Fontanaud, P., Molino, F., Fehrentz, J.A., Carmignac, D., Martinez, J., Guerineau, N.C., Robinson, I.C., Mollard, P. \& Mery, P.F. (2010) Ghrelin stimulation of growth hormonereleasing hormone neurons is direct in the arcuate nucleus. PLoS One, 5, e9159.

Pantel, J., Legendre, M., Cabrol, S., Hilal, L., Hajaji, Y., Morisset, S., Nivot, S., Vie-Luton, M.P., Grouselle, D., de Kerdanet, M., Kadiri, A., Epelbaum, J., Le Bouc, Y. \& Amselem, S. (2006) Loss of constitutive activity of the growth hormone secretagogue receptor in familial short stature. J Clin Invest, 116, 760-768.

Pazos, Y., Casanueva, F.F. \& Camiña, J.P. (2008) Basic Aspects of Ghrelin Action. Vitamins and hormones, 77, 89-119.

Portelli, J., Thielemans, L., Ver Donck, L., Loyens, E., Coppens, J., Aourz, N., Aerssens, J., Vermoesen, K., Clinckers, R., Schallier, A., Michotte, Y., Moechars, D., Collingridge, G.L., Bortolotto, Z.A. \& Smolders, I. (2012) Inactivation of the constitutively active ghrelin receptor attenuates limbic seizure activity in rodents. Neurotherapeutics, 9, 658-672.

Pringos, E., Crouzin, N., Cavalier, M., Guiramand, J., Cohen-Solal, C., Martinez, J., Vignes, M. \& Rolland, V. (2012) Synthesis and characterization of a cyclooctapeptide analogue of omega-agatoxin IVB enhancing the activity of Cav2.1 calcium channels activity in cultured hippocampal neurons. Neurochem Int, 61, 632639. 
Ribeiro, L.F., Catarino, T., Santos, S.D., Benoist, M., van Leeuwen, J.F., Esteban, J.A. \& Carvalho, A.L. (2014) Ghrelin triggers the synaptic incorporation of AMPA receptors in the hippocampus. Proc Natl Acad Sci U S A, 111, E149-158.

Shi, L., Bian, X., Qu, Z., Ma, Z., Zhou, Y., Wang, K., Jiang, H. \& Xie, J. (2013) Peptide hormone ghrelin enhances neuronal excitability by inhibition of Kv7/KCNQ channels. Nature communications, 4, 1435.

Sun, Q., Zang, W.J. \& Chen, C. (2010) Growth hormone secretagogues reduce transient outward $\mathrm{K}+$ current via phospholipase $\mathrm{C}$ /protein kinase $\mathrm{C}$ signaling pathway in rat ventricular myocytes. Endocrinology, 151, 1228-1235.

Sun, Y., Shi, N., Li, H., Liu, K., Zhang, Y., Chen, W. \& Sun, X. (2014) Ghrelin suppresses Purkinje neuron P-type $\mathrm{Ca}(2+)$ channels via growth hormone secretagogue type 1a receptor, the betagamma subunits of Go-protein, and protein kinase a pathway. Cell Signal, 26, 2530-2538.

Sweatt, J.D. (2004) Mitogen-activated protein kinases in synaptic plasticity and memory. Curr Opin Neurobiol, 14, 311-317.

Weisskopf, M.G., Castillo, P.E., Zalutsky, R.A. \& Nicoll, R.A. (1994) Mediation of hippocampal mossy fiber long-term potentiation by cyclic AMP. Science, $\mathbf{2 6 5}$, 1878-1882.

Yang, Y.L., Atasoy, D., Su, H.H. \& Sternson, S.M. (2011) Hunger States Switch a Flip-Flop Memory Circuit via a Synaptic AMPK-Dependent Positive Feedback Loop. Cell, 146, 991-1002. 
[ghrelin] $=1 \mathrm{nM}$

A
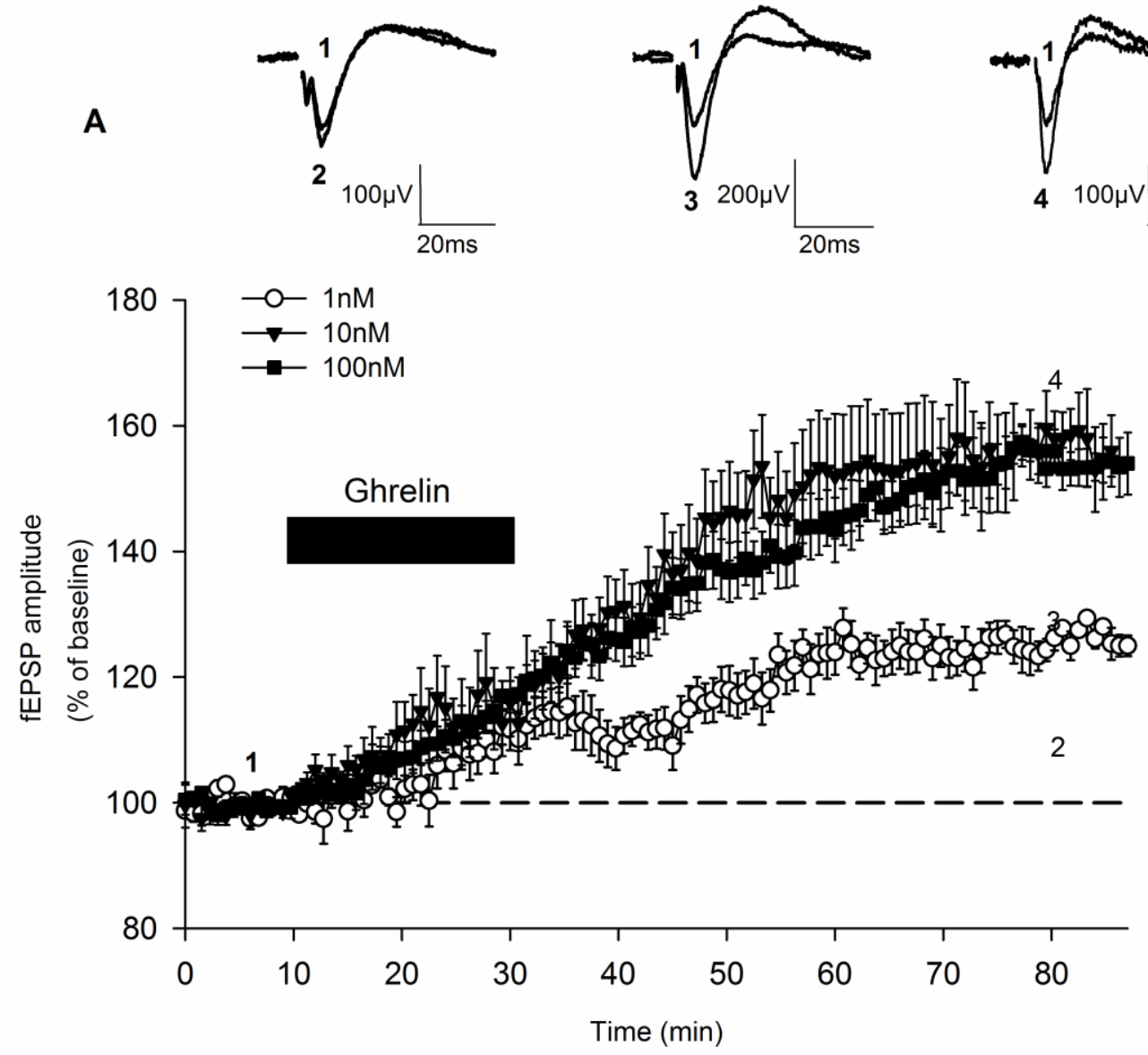

B
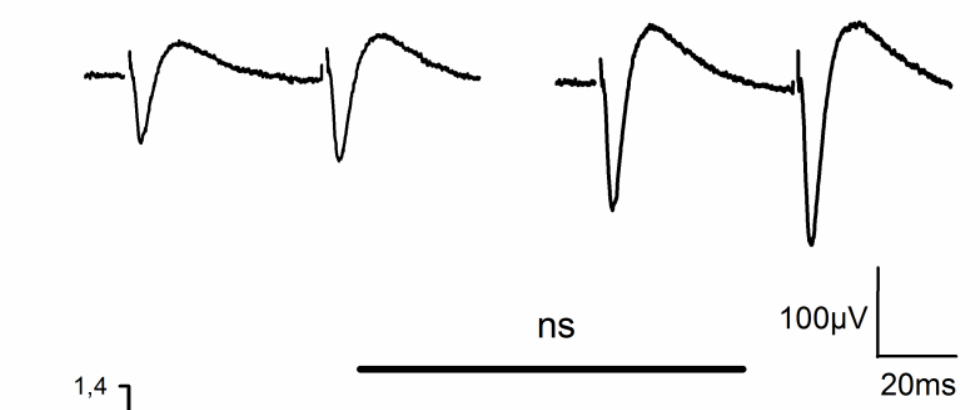

This article is protected by copyright. All rights reserved. 

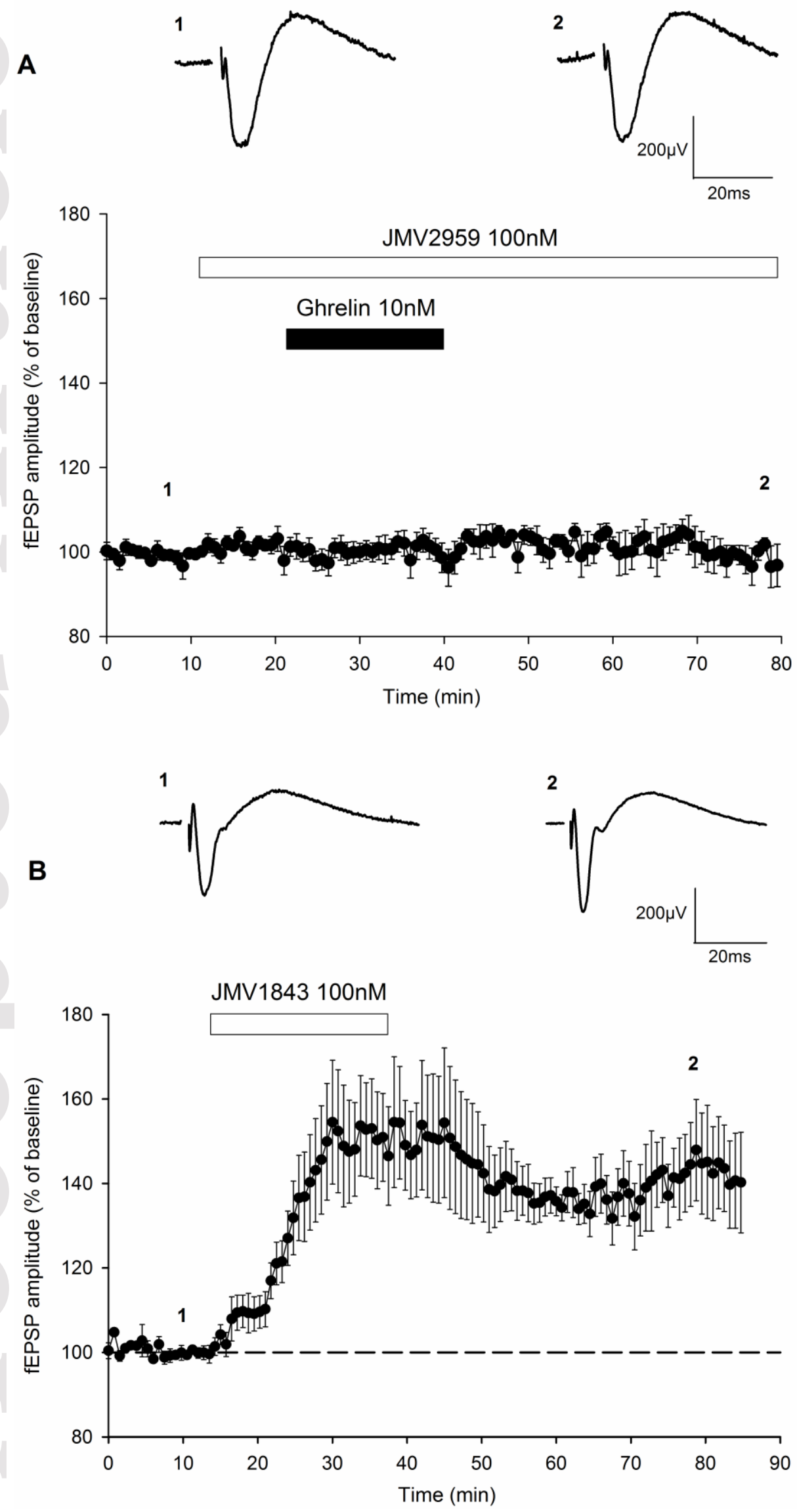

This article is protected by copyright. All rights reserved. 
1

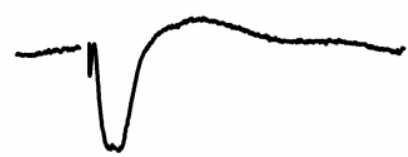

2

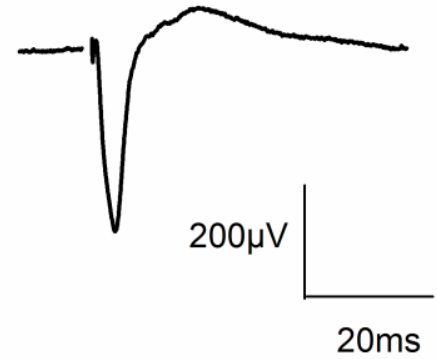

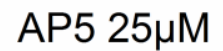

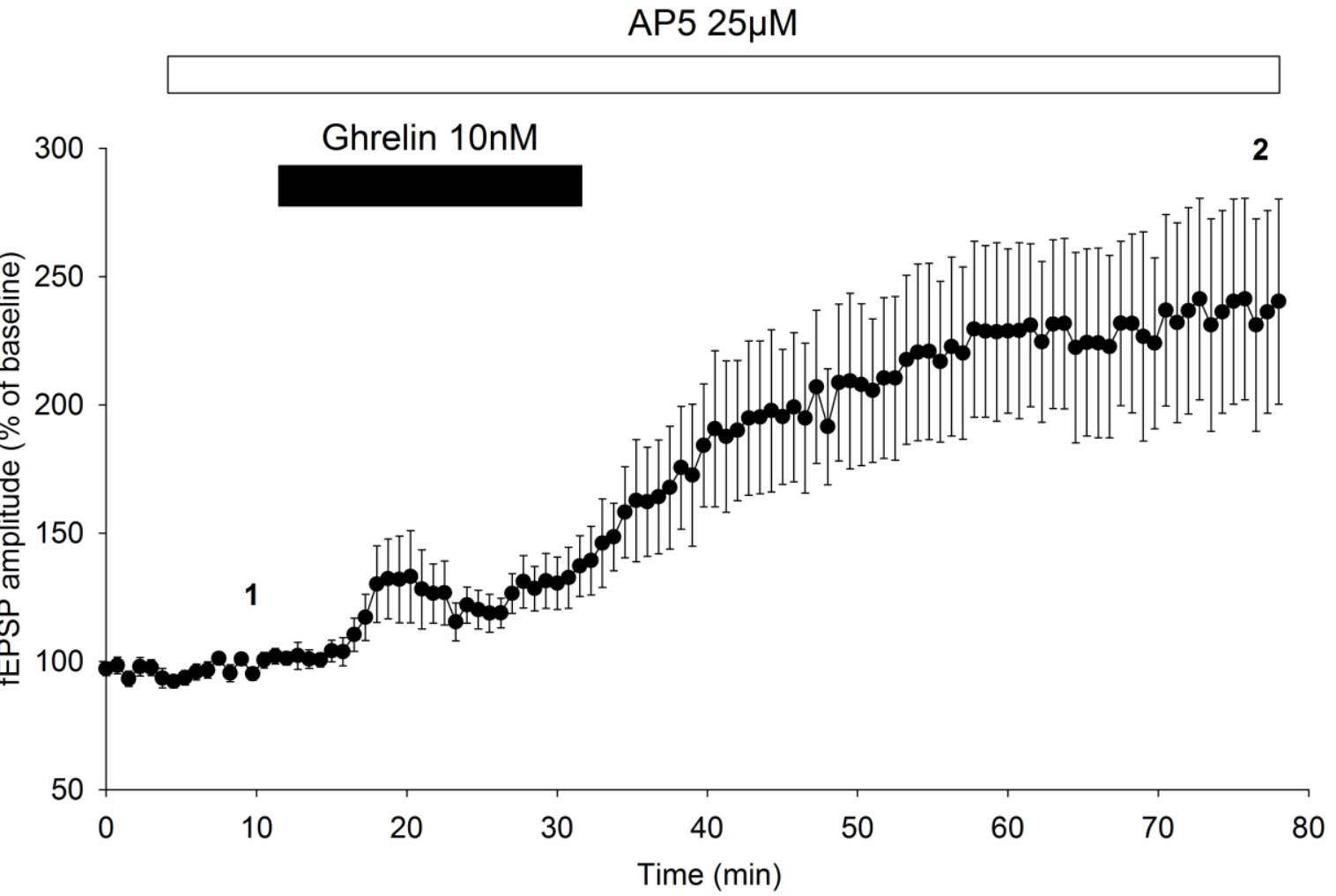

This article is protected by copyright. All rights reserved. 

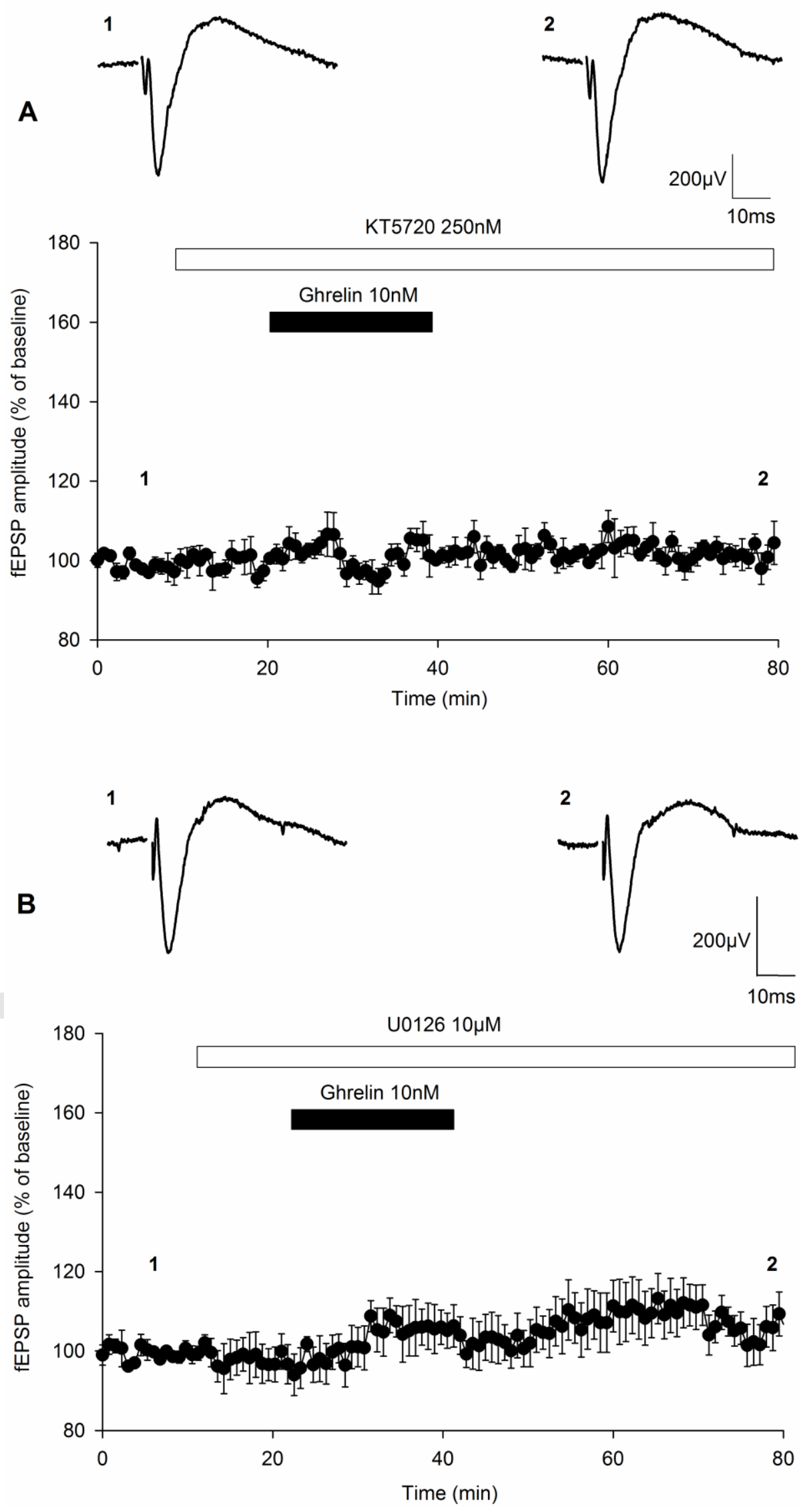

This article is protected by copyright. All rights reserved. 

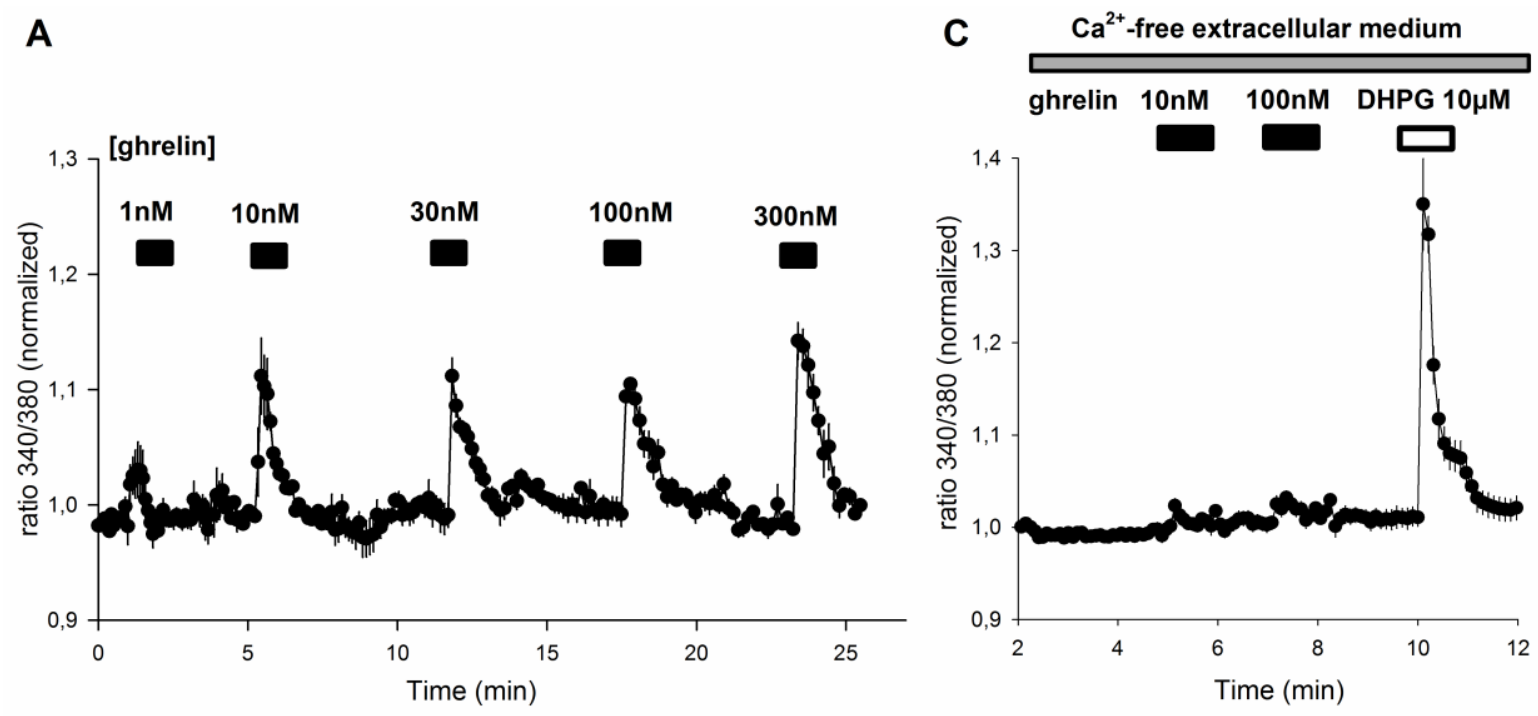

B
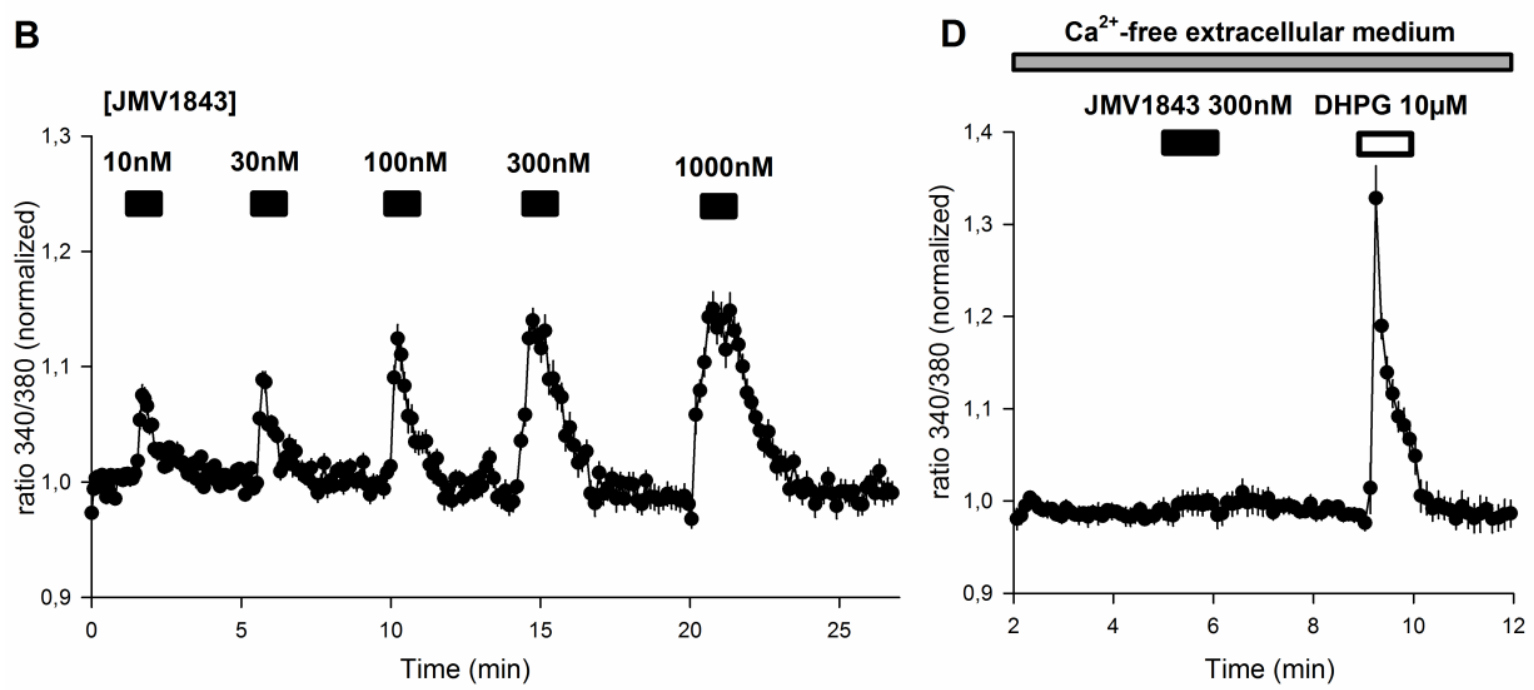

E

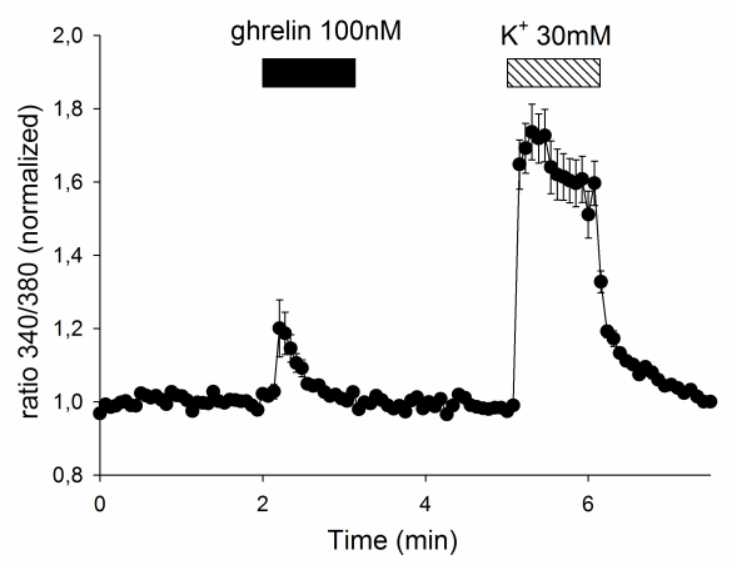

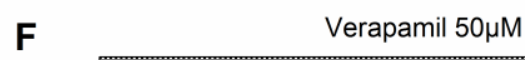

F

Verapamil $50 \mu \mathrm{M}$

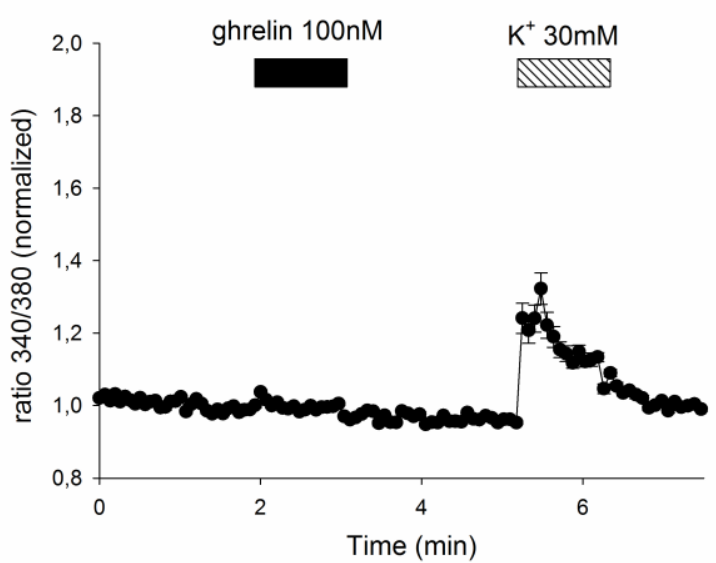

This article is protected by copyright. All rights reserved. 

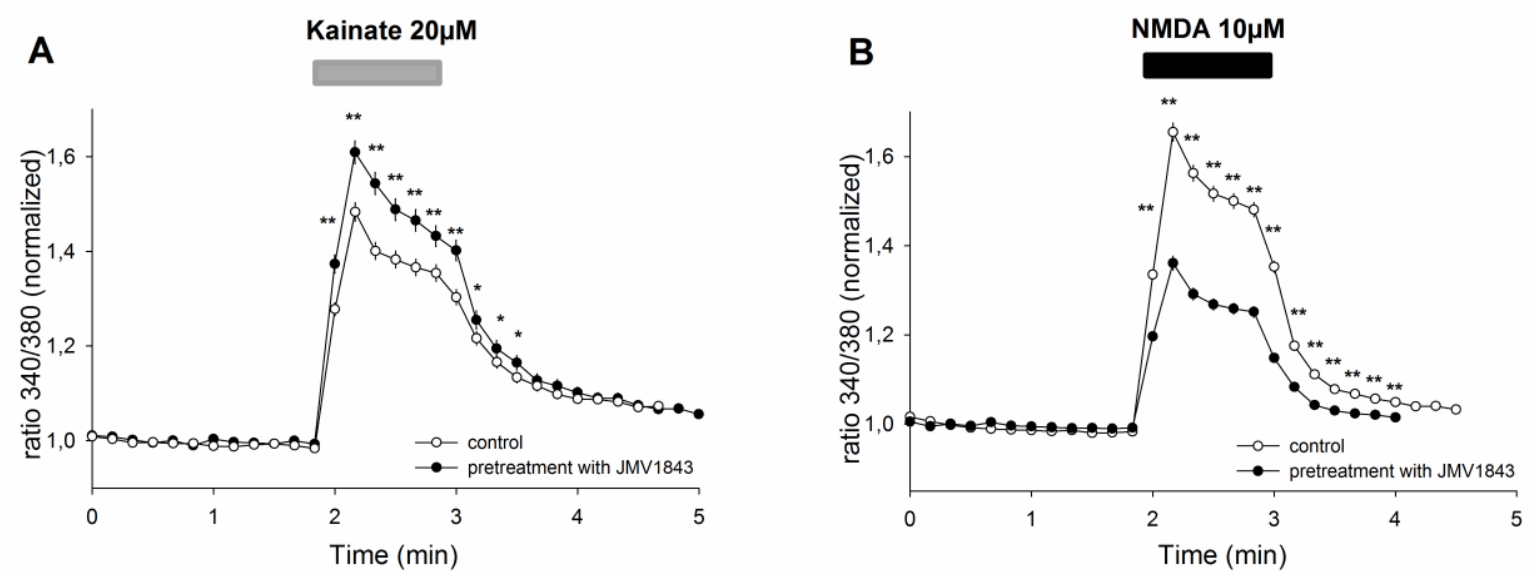

This article is protected by copyright. All rights reserved. 